\title{
Reduction of Opportunistic Illness
}

National Cancer Institute

\section{Source}

National Cancer Institute. Reduction of Opportunistic IIIness. NCI Thesaurus. Code C18994.

Undertake epidemiologic research to reduce or prevent the occurrence of Ols in HIVinfected persons. 